\title{
Expression of growth and differentiation Factor 9 and cognate receptors during final follicular growth in cattle
}

\author{
C.S. Haas ${ }^{1}$, M.T. Rovani ${ }^{2}$, F.C. Oliveira ${ }^{1}$, A.D. Vieira ${ }^{1}$, V. Bordignon ${ }^{3}$, P.B.D. Gonçalves ${ }^{2}$, R. Ferreira ${ }^{4}$, \\ B.G. Gasperin ${ }^{1,5}$ \\ ${ }^{1}$ Faculdade de Veterinária, Universidade Federal de Pelotas, Pelotas, RS, Brazil. \\ ${ }^{2}$ Departamento de Clínica de Grandes Animais, Universidade Federal de Santa Maria, Santa Maria, RS, Brazil. \\ ${ }^{3}$ Departmento de Ciências Animais, McGill University, Sainte Anne de Bellevue, QC, Canada. \\ ${ }^{4}$ Departmento de Ciências Animais, Universidade do Estado de Santa Catarina, Chapecó, SC, Brazil.
}

\begin{abstract}
Mutations in growth and differentiation factor 9 (GDF9) gene are associated to sterility or, paradoxically, increased ovulation rate in ewes. Despite its importance, the exact function of GDF9 in ovarian physiology is still poorly understood. This study aimed to investigate GDF9 function during dominant follicle growth and its regulation in follicular fluid. The regulation of GDF9 receptors in GnRH/LH-stimulated granulosa cells was also investigated. In a first experiment, a new follicular wave was induced and the intrafollicular GDF9 treatment into the largest growing follicle $(8.5-9.5 \mathrm{~mm})$ at both $100(\mathrm{n}=3)$ and $1000 \mathrm{ng} / \mathrm{ml}$ $(\mathrm{n}=4)$ had no effect on follicular growth, estrus manifestation and ovulation compared to control (PBSinjected) follicles $(n=3)$. In a second experiment, follicles were obtained just after follicular deviation (day 4 after follicular emergence) and the abundance of GDF9 in follicular fluid did not differ between healthy dominant $(\mathrm{n}=4)$ and atretic subordinate follicles $(\mathrm{n}=$ 4), as assessed by western blot analysis. Finally, mRNA expression of $B M P R 2$ and $T G F B R 1$ receptors was evaluated in granulosa cells obtained from preovulatory follicles ( $>12 \mathrm{~mm}$ diameter) obtained $0,3,6,12$ or $24 \mathrm{~h}$ after i.m. GnRH administration (n = 4-5 follicles/moment). Both receptors were significantly up regulated $12 \mathrm{~h}$ after $\mathrm{GnRH}$ treatment. Present results do not confirm the hypothesis that GDF9 inhibits dominant follicle growth and suggests a minor role in determining follicle fate. In the other hand, GDF9 receptors regulation in $\mathrm{GnRH} / \mathrm{LH}$-stimulated granulosa cells provides the first in vivo evidence of its involvement in the complex cascade of events that culminates in ovulation and luteinization in cattle.
\end{abstract}

Keywords: folliculogenesis, oocyte factors, ovulation.

\section{Introduction}

Folliculogenesis and follicle differentiation are processes that culminate in ovulation, being mainly coordinated by well-established endocrine mechanisms. In monovulatory species, from a cohort of growing follicles, only one is selected to continue growing (dominant follicle), whereas all the others undergo atresia (subordinate follicles; Ginther et al., 1996).
Since all the follicles are under the same endocrine environment, ovarian-produced factors are also involved in dominant follicle selection, regulating important events such as proliferation of granulosa cells, differentiation and steroidogenesis. In this context, the involvement of oocyte-secreted factors such as growth and differentiation factor 9 (GDF9), bone morphogenetic protein 15 (BMP15) and their receptors, has been demonstrated in sheep (Knight and Glister, 2006). Both proteins seem to interact to regulate important ovarian functions (Galloway et al., 2000; Juengel, 2002; Hanrahan et al., 2004).

Spontaneous heterozygous inactivating mutations in BMP15 and GDF9 genes induce superovulation, whereas homozygous mutation (absence of functional protein) causes sterility in ewes as a consequence of impaired preantral follicle development (Galloway et al., 2000; Hanrahan et al., 2004). These interesting findings were reproduced using passive and active immunization against these proteins. In both sheep and cattle, short-term immunization increased ovulation rate (Juengel et al., 2004b, 2009), with no negative effects on fertilization, embryo development and pregnancy maintenance in ewes (Juengel et al., 2004b).

On the other hand, long-term immunization blocked follicle development in sheep (McNatty et al., 2007). Furthermore, passive immunization against GDF9 negatively affected ovulation and luteinization (Juengel, 2002), suggesting the involvement of this protein during the periovulatory period. In cattle, GDF9 stimulates theca cells proliferation but inhibits $\mathrm{LH}$ or IGF-stimulated steroidogenesis by downregulation of CYP11A1 enzyme and LH receptors (LHCGR) in vitro. A negative effect of GDF9 was also observed on estradiol secretion by granulosa cells treated with FSH and IGF in vitro (Spicer et al., 2008). Taken together, these studies demonstrate that BMP15/GDF9 are essential during preantral follicle development, but are also involved in final follicular growth and ovulation (Juengel et al., 2004a, 2009). However, the regulation and function of these proteins, especially during periovulatory period, is still poorly understood.

In humans, deregulation of BMPs expression is associated with reproductive dysfunction such as premature ovarian failure (Dixit et al., 2006). Reduced BMP15 and GDF9 expression was also reported in 
women with polycistic ovary syndrome (PCOS; Wei et al., 2014). Furthermore, a mutation in GDF9 was identified in young women with reduced ovarian reserve, being associated to reduced production of mature protein, decreasing GDF9 effect on human granulosa cells proliferation in vitro (Wang et al., 2013).

The growing evidence of the involvement of oocyte-secreted factors in regulating follicle development led to many in vitro studies to investigate their regulation and mechanisms of action. However, only a few studies have investigated the regulation of these proteins in different follicle classes and by gonadotrophins in vivo. Furthermore, to the best of our knowledge, there is no study manipulating GDF9 or BMP15 concentration in follicular environment. Thus, the present study aimed to determine the effect of GDF9 intrafollicular injection on follicular growth and compare its abundance in healthy and atretic follicles after follicular deviation. Furthermore, GDF9 receptors regulation during $\mathrm{GnRH} / \mathrm{LH}$-induced ovulation was also investigated.

\section{Material and Methods}

All procedures involving animals were reviewed and approved by the UFPel's and/or UFSM Ethics for Animal Experimentation Committees.

\section{Experiment 1: Follicular growth and ovulation after GDF9 intrafollicular injection}

The effect of recombinant human GDF9 (rhGDF9; Sigma Aldrich) intrafollicular injection was investigated in non-lactating cyclic cows from Holstein and Jersey breeds. Cows were synchronized using a hormonal protocol (Zoetis, São Paulo, Brazil) consisting of $2 \mathrm{mg}$ estradiol benzoate i.m. injection and insertion of an intravaginal device (IVD) containing $1 \mathrm{~g}$ progesterone on day 0 to induce follicular regression and a new follicular wave. Seven days later, prostaglandin F2 $\alpha$ (25 mg, i.m.) was administered to induce corpus luteum regression and daily follicular dynamics evaluation was initiated. IVDs were kept until growing follicles reached 8.5 to $9.5 \mathrm{~mm}$ diameter, when intrafollicular injections were performed. At least two transrectal ultrasound examinations using a $6 \mathrm{MHz}$ linear-array transducer (Pie Medical AquilaVet, Maastricht, The Netherlands) were performed before intrafollicular injection, to ensure that the follicles were growing. All structures larger than $6 \mathrm{~mm}$ were drawn according to their position in the ovaries. After identifying the healthy dominant follicle from each cow, treatments were performed followed by daily transrectal ultrasound evaluation. Intrafollicular injections were performed under caudal epidural anesthesia using $80 \mathrm{mg}$ lidocaine chlorhydrate (4 $\mathrm{ml}$ lidocaine $2 \%$ ) using a twoneedles system attached to a $5 \mathrm{MHz}$ microconvex-array transducer (Pie Medical AquilaVet, Maastricht, The Netherlands) according to Ferreira et al. (2007). Injected follicles were daily monitored until follicular regression (atresia) or spontaneous ovulation.
Cows were randomly allocated to receive an intrafollicular injection of phosphate buffered saline (PBS, control group; $\mathrm{n}=3$ ) or recombinant human GDF9 (rhGDF9; Sigma Aldrich) at final concentrations of $100(n=3)$ or $1000(n=4) n g / m l$. The doses of rhGDF9 were chosen based on in vitro studies (Mottershead et al., 2011). The injected volume was determined according to the linear equation $\mathrm{V}=-685.1$ $+120.7 \mathrm{D}$, where "V" corresponds to the volume in microliters and " $D$ " to the diameter of the follicle in millimeters (Ferreira et al., 2007). The initial concentration of rhGDF9 was 10 times greater than the desired final intrafollicular concentration.

\section{Experiment 2: Follicular fluid GDF9 abundance in dominant and subordinate follicles after deviation}

To compare GDF9 protein abundance between healthy dominant and regressing (atretic) follicles (day 4 of follicular wave), follicular fluid samples from a previous study were used (Gasperin et al., 2014). Briefly, ovaries from four previously synchronized nonlactating cyclic Bos taurus cows (Red Angus, 400-500 $\mathrm{kg}$ body weight) where obtained on day 4 after follicular emergence (D0 was retrospectively identified as the last day when the largest follicle was smaller than $5 \mathrm{~mm}$ ). Follicular fluid samples from the two largest follicles from each cows were obtained through aspiration. To quantify GDF9 protein abundance, western blots were run using $70 \mu \mathrm{g}$ protein samples. After boiling at $95{ }^{\circ} \mathrm{C}$ for $5 \mathrm{~min}$, follicular fluid samples were subjected to $12 \%$ SDS gel and electrotransferred onto nitrocellulose membranes. After blocking for $2 \mathrm{~h}$ with $5 \%$ skimmed milk in PBS containing 0.1\% tween-20 (PBS-T), blots were incubated overnight at $4^{\circ} \mathrm{C}$ with 1:500 rabbit antihuman GDF9 (GTX108410; GeneTex., CA, USA) with agitation, followed by three washes (10 min each) with PBS-T. Then, blots were incubated with 1:5000 goat antirabbit IgG-HRP (ab6721; Abcam Inc., USA) for $2 \mathrm{~h}$ with agitation, followed by three washes (10 min each) with PBS-T. Finally, immunoreactivity was detected with Immun-Star WesternC Chemiluminescence Kit according to the manufacturer's instructions and visualized using Chemidoc analyser (BioRad, CA, USA). Quantification of GDF9 bands of the western blots was performed using Image Lab software (BioRad Laboratory).

Experiment 3: Granulosa cells mRNA expression of GDF9 receptors after induction of ovulation with $\mathrm{GnRH}$

Thirty-one cyclic adult (3 to 8 years old) nonlactating Bos taurus cows (predominantly Red Angus and Hereford, 400-500 kg body weight) with body condition scores of 3 and 4 were submitted to a synchronization protocol. The hormonal protocol started on day 0 with the insertion of an intravaginal device (IVD) containing $1 \mathrm{~g}$ progesterone and i.m. injections of $2 \mathrm{mg}$ estradiol benzoate and $250 \mu \mathrm{g}$ cloprostenol (two injections, $12 \mathrm{~h}$ apart). On day 9, IVDs were removed and only cows with follicles $\geq 12 \mathrm{~mm}$ in diameter $(\mathrm{n}=23$ cows) received an i.m. injection of GnRH (100 $\mu \mathrm{g}$ 
gonadorelin acetate). Granulosa cells samples were obtained $0(n=4), 3(n=5), 6(n=4), 12(n=5)$ and $24 \mathrm{~h}(\mathrm{n}=5)$ after GnRH i.m. treatment (Santos et al., 2012).

Granulosa cells total RNA was extracted using AllPrep DNA/RNA/protein kit (Qiagen, Mississauga, ON, Canada). Quantitation and estimation of RNA purity was performed using NanoDrop (Thermo Scientific - Waltham, USA; Abs 260/280 nm ratio) spectrophotometer (ratios above 1.8 were considered pure). To generate the cDNA, $200 \mathrm{ng}$ RNA was first treated with $0.1 \mathrm{U}$ DNase (Invitrogen; $37^{\circ} \mathrm{C}-5 \mathrm{~min}$ ) After DNase inactivation at $65^{\circ} \mathrm{C}$ for $10 \mathrm{~min}$, samples were incubated in a final volume of $20 \mu \mathrm{l}$ with iScript cDNA Synthesis Kit (BioRad) according to the manufacturer's instructions. To avoid crosscontamination, only granulosa cells samples that did not express CYP17A1 mRNA after 30 PCR cycles were used in the study.

Real-time polymerase chain reactions (PCR) were conducted in a CFX384 real-time PCR detection system (BioRad, Hercules, CA) using SsoFast ${ }^{\mathrm{TM}}$ EvaGreen ${ }^{\circledR}$ supermix (BioRad, Hercules, CA) using the following primers sequences: GAPDH: $\mathrm{F}$ GATTGTCAGCAATGCCTCCT and RGGTCATAAGTCCCTCCACGA; CYCLOPHILIN: FGGTCATCGGTCTCTTTGGAA and RTCCTTGATCACACGATGGAA; BMPR2: FCCACTGGCCTCACTCCAAGT and RCCCGACTGGCTGTGAAACAT; and TGFBR1: FACCACTGCAATAAAATAGAACTTCCA and RTGACAGCTGCCAGTTCAACAG. Melting-curve analyses was performed to verify product identity. Samples were run in duplicate using $2 \mu \mathrm{l}$ of diluted cDNA $(1: 20)$ in each well. The relative standard curve method was used to assess the amount of a particular transcript in the samples, as previously described (Gasperin et al., 2014). Results were expressed relative to the average of GAPDH and cyclophilin housekeeping genes.

\section{Statistical analysis}

Main effects of treatment group, day and their interaction on follicular growth were determined using the MIXED procedure (SAS Institute Inc., Cary, NC) with a repeated measure statement. Differences between follicular diameters at a specific time point were compared between groups using estimates. Protein and mRNA abundance data were submitted to ANOVA using JMP software (JMP version 7; SAS Institute Inc., Cary, NC). Comparison between groups was made by least square means. Results are presented as means \pm standard error of the mean (s.e.m) and a $\mathrm{P}<0.05$ was considered statistically significant.

\section{Results}

In the first study, all injected follicles grew independently of treatment (moment effect). Cows from all groups demonstrated estrus and ovulated (Fig. 1). There was no significantly effect of group and no interaction of group and time after intrafollicular injection $(\mathrm{P}>0.05)$.

No significant difference were observed in GDF9 protein abundance in follicular fluid from dominant compared to subordinate follicles collected after follicular deviation ( $\mathrm{P}>0.05$; Fig. 2). Both $B M P R 2$ and TGFRB1 receptors were significant upregulated $12 \mathrm{~h}$ after GnRH treatment (Fig. 3).

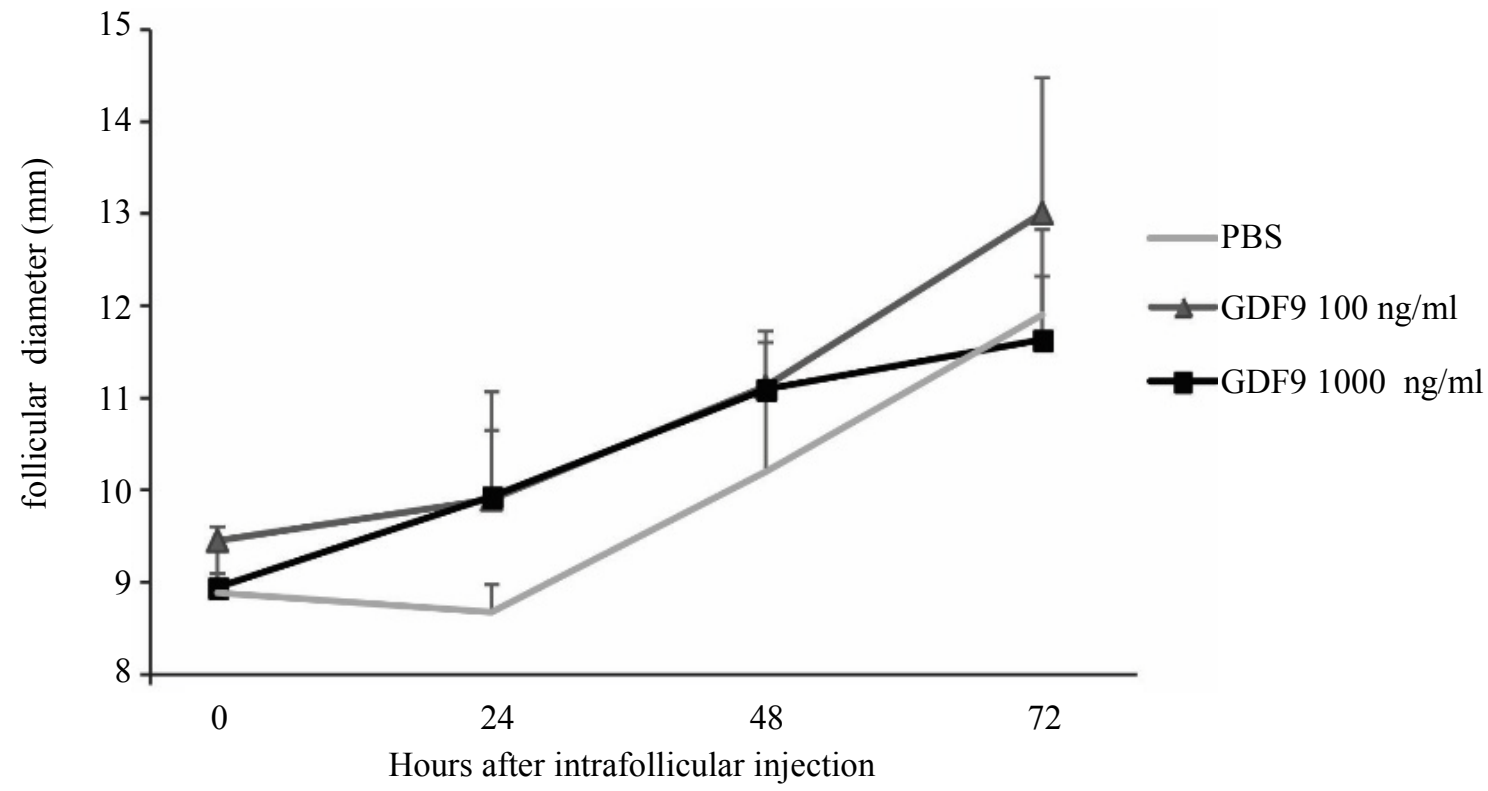

Figure 1. Effect of GDF9 intrafollicular injection on bovine follicular growth. Animals received intrafollicular injection of PBS (control; $n=3)$ or $r h G D F 9$ at $100 \mathrm{ng} / \mathrm{ml}(\mathrm{n}=3)$ or $\mathrm{rhGDF} 9$ at $1000 \mathrm{ng} / \mathrm{ml}(\mathrm{n}=4)$. 


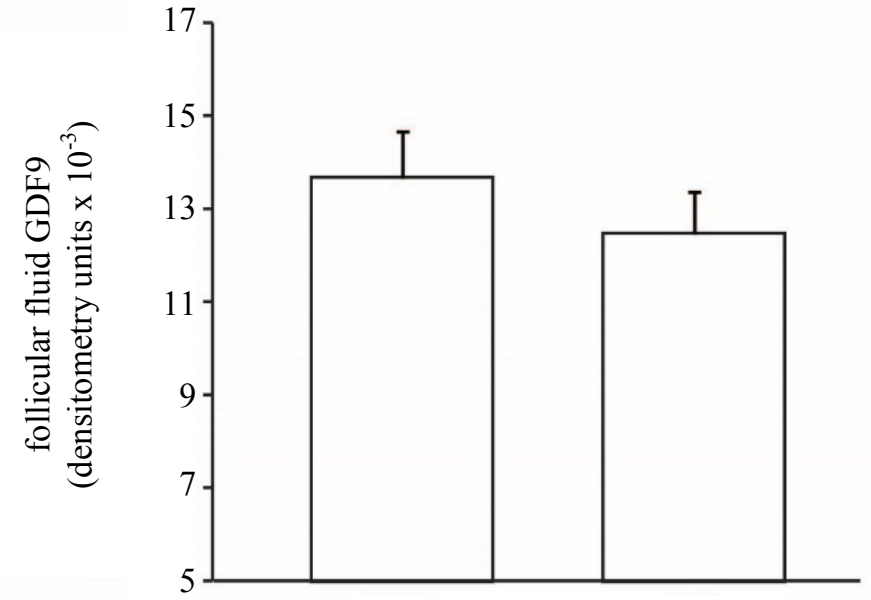

A

DF

SF

B

$50 \mathrm{kDa}$

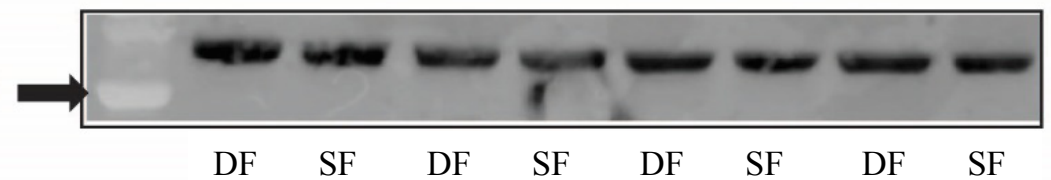

Figure 2. Abundance of GDF9 protein in follicular fluid from dominant (DF; $n=4)$ and subordinate follicles $(\mathrm{SF} ; \mathrm{n}=4)$ obtained after follicular deviation (day 4 of follicular wave).
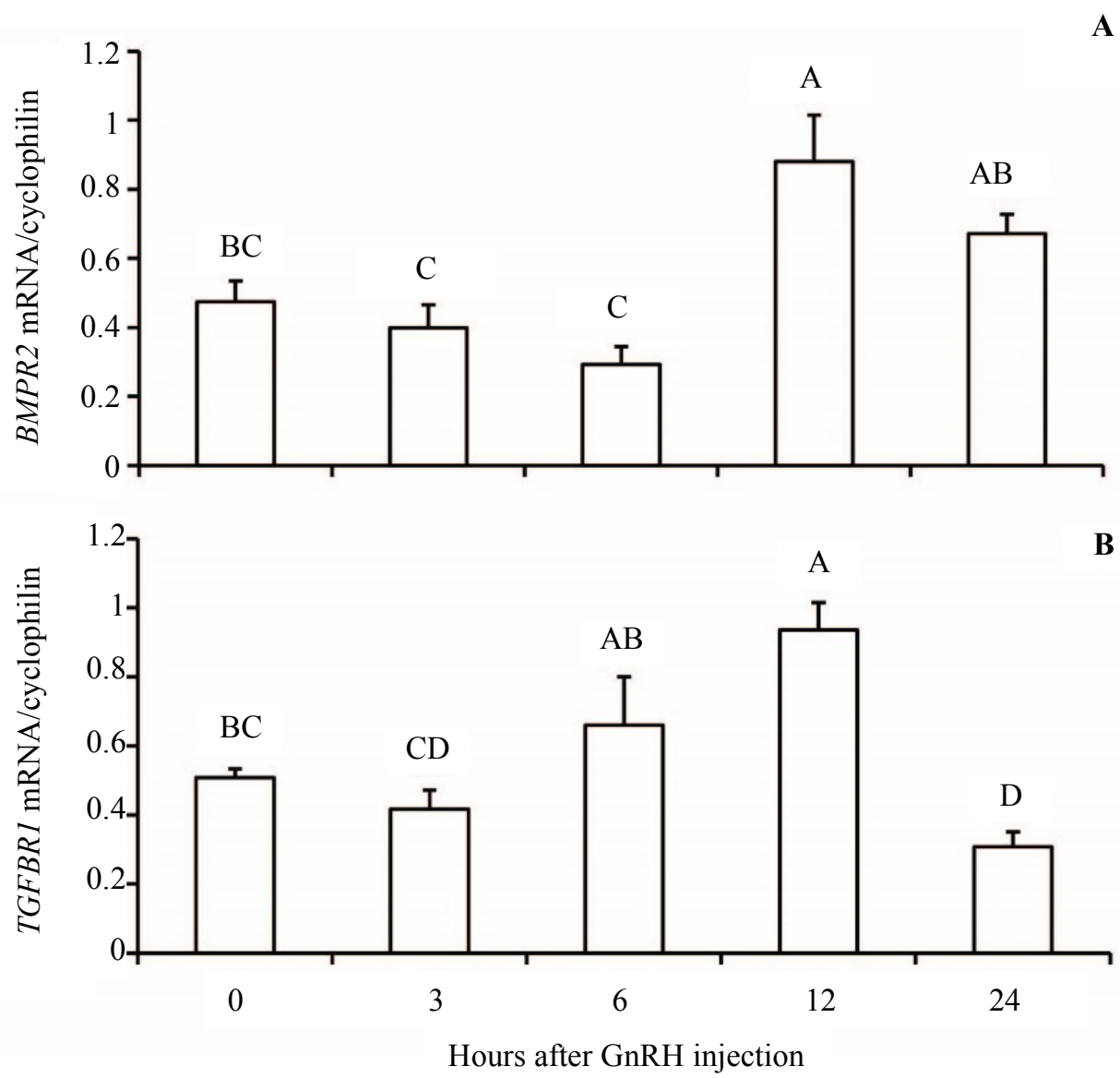

Figure 3. Abundance of $B M P R 2$ (A) and TGFBR1 (B) mRNA in granulosa cells from follicles $>12 \mathrm{~mm}, 0$ ( $\mathrm{n}=4), 3$ $(\mathrm{n}=5), 6(\mathrm{n}=4), 12(\mathrm{n}=5)$ and $24(\mathrm{n}=5)$ hours after $\mathrm{GnRH}$ administration. Different letters indicate significant difference $(\mathrm{P}<0.05)$. 


\section{Discussion}

Oocyte-secreted factors have many different functions varying according to the species and experimental models (McNatty et al., 2005; Spicer et al., 2006). Based on previous results from bovine and ovine in vivo models (Juengel et al., 2004b, 2009) suggesting that GDF9 acts as an inhibitor of granulosa cells differentiation, we hypothesized that its intrafollicular injection would inhibit dominant follicle growth and ovulation. However, using an in vivo model similar to the one used by Lv et al. (2009), GDF9 intrafollicular injection in follicles between 8.5 and 9.5 $\mathrm{mm}$ at final concentrations of 100 or $1000 \mathrm{ng} / \mathrm{ml} \mathrm{did} \mathrm{not}$ affect follicular growth and ovulation. Follicular differentiation in Bos taurus taurus cows occurs when the dominant follicles reach $8.5 \mathrm{~mm}$ and its hallmark is the expression of LH receptors (LHCGR) in granulosa cells, despite $L H C G R$ expression increases in follicles larger than $9 \mathrm{~mm}$ (Gasperin et al., 2015). Thus, a possible explanation for the lack of GDF9 effect is that injected follicles were already differentiated. GDF9 treatment in follicles around 7.5 and $8 \mathrm{~mm}$ should be performed in future studies to investigate a possible effect in inhibiting follicle differentiation (Gasperin et al., 2012), since previous studies demonstrated that cells from small follicles ( 3 to $6 \mathrm{~mm}$ ) are more susceptible to GDF9 effects on proliferation and steroidogenesis (Spicer et al., 2008). Unfortunately, it is not possible to perform intrafollicular injections in follicles smaller than $6 \mathrm{~mm}$.

Corroborating the aforementioned results, GDF9 abundance did not differ between follicular fluid collected from healthy dominant compared to atretic subordinate follicles. Based on previous studies suggesting an inhibitory role of GDF9 on antral follicle differentiation, we would expect decreased abundance in healthy growing follicles. However, in a previous study, GDF9 cognate receptors BMPR2 and TGFBR1 were not regulated at the expected moment of follicular deviation and after the establishment of follicular dominance in cattle (Gasperin et al., 2014). GDF9 abundance was previously quantified in human follicular fluid, being mature protein levels positively correlated with nuclear maturation and embryo quality and negatively correlated to follicular fluid progesterone levels (Gode et al., 2011), suggesting that GDF9 levels decrease during luteinization. However, in primates, GDF9 levels in follicular fluid were not altered after hCG treatment (Duffy, 2003). It is important to highlight that in the present study we only quantified the abundance of GDF9 pre-peptide and that posttranslation modifications and interaction with other proteins may differentially regulate GDF9 function.

To investigate the previously-demonstrated association between GDF9 signaling and steroidogenesis (Juengel, 2002; Spicer et al., 2008), the expression of $B M P R 2$ and TGFBR1 mRNA was evaluated in granulosa cells from $\mathrm{GnRH} / \mathrm{LH}$-stimulated preovulatory follicles in vivo (Santos et al., 2012). The significant increase in BMPR2 and TGFBR1 $12 \mathrm{~h}$ after GnRH treatment, suggests an involvement in steroidogenesis regulation, since at this time-point estradiol levels sharply decrease (Santos et al., 2012), preceding the increase in follicular fluid progesterone levels (Fortune et al., 2009). Thus, beyond its role in granulosa cells steroidogenesis in small follicles (Spicer et al., 2006, 2008), GDF9 may regulate steroidogenesis during luteinization in cattle.

Collectively, present results do not confirm the hypothesis that the oocyte secreted factor GDF9 inhibits dominant follicle growth in cattle. The fact that GDF9 protein abundance does no differ in healthy and atretic follicles suggests that this factor has a minor role in determining follicle fate. In the other hand, the regulation of GDF9 receptors in granulosa cells after $\mathrm{GnRH} / \mathrm{LH}$ treatment provides the first in vivo evidence of its involvement in the complex cascade of events that culminates in ovulation and luteinization in cattle.

\section{Acknowledgments}

This study was sponsored by Conselho Nacional de Desenvolvimento Científico e Tecnológico $(\mathrm{CNPq})$ and Fundação de Amparo à Pesquisa do Estado do Rio Grande do Sul (FAPERGS). C.S. Haas was supported by a Coordenação de Aperfeiçoamento de Pessoal de Nível Superior (CAPES) fellowship.

\section{References}

Dixit H, Rao L, Padmalatha V, Kanakavalli M, Deenadayal M, Gupta N, Chakrabarty B, Singh L. 2006. Missense mutations in the BMP15 gene are associated with ovarian failure. Hum Genet, 119:408415.

Duffy DM. 2003. Growth differentiation factor-9 is expressed by the primate follicle throughout the periovulatory interval. Biol Reprod, 69:725-732.

Ferreira R, Oliveira JF, Fernandes R, Moraes JF, Goncalves PB. 2007. The role of angiotensin II in the early stages of bovine ovulation. Reproduction, 134:713-719.

Fortune JE, Willis EL, Bridges PJ, Yang CS. 2009. The periovulatory period in cattle: progesterone, prostaglandins, oxytocin and ADAMTS proteases. Anim Reprod, 6:60-71.

Galloway SM, McNatty KP, Cambridge LM, Laitinen MP, Juengel JL, Jokiranta TS, McLaren RJ, Luiro K, Dodds KG, Montgomery GW, Beattie AE, Davis GH, Ritvos O. 2000. Mutations in an oocyte-derived growth factor gene (BMP15) cause increased ovulation rate and infertility in a dosagesensitive manner. Nat Genet, 25:279-283.

Gasperin B, Ferreira R, Rovani MT, Santos JT, Buratini Jr. J, Price C, Gonçalves PB. 2012. FGF10 inhibits dominant follicle growth and estradiol secretion in vivo in cattle. Reproduction, 143:815-23

Gasperin BG, Ferreira R, Rovani MT, Bordignon V, Duggavathi R, Buratini J, Oliveira JFC, Gonçalves PBD. 2014. Expression of receptors for BMP15 is differentially regulated in dominant and subordinate follicles during follicle deviation in cattle. Anim Reprod Sci, 144:72-78. 
Gasperin BG, Rovani MT, Ferreira R, Ilha GF, Bordignon V, Gonçalves PBD, Duggavathi R. 2015. Functional status of STAT3 and MAPK3/1 signaling pathways in granulosa cells during bovine follicular deviation. Theriogenology, 83:353-359.

Ginther OJ, Wiltbank MC, Fricke PM, Gibbons JR, Kot K. 1996. Selection of the dominant follicle in cattle. Biol Reprod, 55:1187-1194.

Gode F, Gulekli B, Dogan E, Korhan P, Dogan S, Bige O, Cimrin D, Atabey N. 2011. Influence of follicular fluid GDF9 and BMP15 on embryo quality. Fertil Steril, 95:2274-2278.

Hanrahan JP, Gregan SM, Mulsant P, Mullen M, Davis GH, Powell R, Galloway SM. 2004. Mutations in the genes for oocyte-derived growth factors GDF9 and BMP15 are associated with both increased ovulation rate and sterility in cambridge and belclare sheep (Ovis aries). Biol Reprod, 70:900-909.

Juengel JL. 2002. Growth differentiation factor 9 and bone morphogenetic protein 15 are essential for ovarian follicular development in sheep. Biol Reprod, 67:17771789.

Juengel JL, Bodensteiner KJ, Heath DA, Hudson NL, Moeller CL, Smith P, Galloway SM, Davis GH, Sawyer HR, McNatty KP. 2004a. Physiology of GDF9 and BMP15 signalling molecules. Anim Reprod Sci, 82/83:447-460.

Juengel JL, Hudson NL, Whiting L, McNatty KP. 2004b. Effects of immunization against bone morphogenetic protein 15 and growth differentiation factor 9 on ovulation rate, fertilization, and pregnancy in ewes. Biol Reprod, 70:557-561.

Juengel JL, Hudson NL, Berg M, Hamel K, Smith P, Lawrence SB, Whiting L, McNatty KP. 2009. Effects of active immunization against growth differentiation factor 9 and/or bone morphogenetic protein 15 on ovarian function in cattle. Reproduction, 138:107-114.

Knight PG, Glister C. 2006. TGF-\{beta $\}$ superfamily members and ovarian follicle development. Reproduction, 132:191-206.

Lv L, Jimenez-Krassel F, Sen A, Bettegowda A, Mondal M, Folger JK, Lee K-B, Ireland JJ, Smith GW. 2009. Evidence supporting a role for cocaine- and amphetamine-regulated transcript (CARTPT) in control of granulosa cell estradiol production associated with dominant follicle selection in cattle. Biol Reprod, 81:580-586.

McNatty KP, Juengel JL, Reader KL, Lun S, Myllymaa S, Lawrence SB, Western A, Meerasahib MF, Mottershead DG, Groome NP, Ritvos O, Laitinen MPE. 2005. Bone morphogenetic protein 15 and growth differentiation factor 9 co-operate to regulate granulosa cell function. Reproduction, 129:473-480.

McNatty KP, Hudson NL, Whiting L, Reader KL, Lun S, Western A, Heath DA, Smith P, Moore LG, Juengel JL. 2007. The effects of immunizing sheep with different BMP15 or GDF9 peptide sequences on ovarian follicular activity and ovulation rate. Biol Reprod, 76:552-560.

Mottershead DG, Ritter LJ, Gilchrist RB. 2011. Signalling pathways mediating specific synergistic interactions between GDF9 and BMP15. Mol Hum Reprod, 18:121-128.

Santos JT, Ferreira R, Gasperin BG, Siqueira LC, de Oliveira JF, Santos RA, Reis AM, Gonçalves PB. 2012. Molecular characterization and regulation of the angiotensin-converting enzyme type 2/Angiotensin-(17)/MAS receptor axis during the ovulation process in cattle. J Renin Angiotensin Aldosterone Syst, 13:91-98.

Spicer LJ, Aad PY, Allen D, Mazerbourg S, Hsueh AJ. 2006. Growth differentiation factor-9 has divergent effects on proliferation and steroidogenesis of bovine granulosa cells. J Endocrinol, 189:329-339.

Spicer LJ, Aad PY, Allen DT, Mazerbourg S, Payne AH, Hsueh AJ. 2008. Growth differentiation factor 9 (GDF9) stimulates proliferation and inhibits steroidogenesis by bovine theca cells: influence of follicle size on responses to GDF9. Biol Reprod, 78:243-253.

Wang T-T, Ke Z-H, Song Y, Chen L-T, Chen X-J, Feng C, Zhang D, Zhang R-J, Wu Y-T, Zhang Y, Sheng J-Z, Huang H-F. 2013. Identification of a mutation in GDF9 as a novel cause of diminished ovarian reserve in young women. Hum Reprod, 28:2473-2481

Wei L-N, Huang R, Li L-L, Fang C, Li Y, Liang XY. 2014. Reduced and delayed expression of GDF9 and BMP15 in ovarian tissues from women with polycystic ovary syndrome. J Assist Reprod Genet, 31:1483-1490. 